\title{
PELAKSANAAN PENYIMPANAN ARSIP DI BAGIAN KASUBAG KEPEGAWAIAN DINAS PENDIDIKAN PROVINSI SUMATERA BARAT
}

\author{
Honesty Akmal 1 \\ Program Studi Informasi, Perpustakaan dan Kearsipan, Fakultas Bahasa dan Seni, \\ Universitas Negeri Padang \\ Honestyakmaal@gmail.com
}

Elva Rahmah ${ }^{2}$

Universitas Negeri Padang

\begin{abstract}
Abstrak
Archive is a record of activities or documents created by institutions that are stored every day that have a use value that can be found at any time. In the process of carrying out archival storage, it requires an archival storage system that is specified so that archived documents can be organized, and are easy to find if needed, the system used is a subject system where storage is based on document content, date system, where documents are ordered by the date the document was created and geographical system or territory, where storage is arranged based on the area the document originated or intended. Adequate equipment and equipment, supporting the filing process, this activity was not immune from human resources who could operate the equipment and equipment properly. The system used is decentralization, which is Archive Management which is carried out in each work unit in an organization or each unit manages its archives.
\end{abstract}

Kata Kunci: Archive; decentralization system

\section{A. PENDAHULUAN}

Dalam kegiatan sehari- hari, instansi atau lembaga baik pemerintah atau swasta, tidak lepas dari penciptaaan arsip seperti surat menyurat atau bentuk dokumen lainnya yang akan menunjukan apa yang dilakukan lembaga atau instasi pada saat itu dan apa yang terjadi, sehingga melalui arsip akan dapat diketahui apa yang sebenarnya terjadi dari waktu ke waktu. Arsip merupakan rekaman suatu kegiatan, yang sewaktu- waktu di perlukan sebagai sumber informasi, yang memiliki nilai guna di kemudian hari dan dapat dijadikan sebagai bukti untuk suatu tindakan dan keputusan. Arsip yang diperoleh bisa berbentuk naskah, dokumen, bisa berupa tulisan, gambar audio dan video. Berdasarkan UU No. 43 Tahun 2009, pengertian arsip yaitu Arsip adalah 
Published by Program Studi Perpustakaan dan IImu Informasi FBS Universitas Negeri Padang, Indonesia

rekaman kegiatan atau peristiwa dalam berbagai bentuk dan media sesuai dengan perkembangan teknologi informasi dan komunikasi yang dibuat dan diterima oleh lembaga negara, pemerintahan daerah, lembaga pendidikan, perusahaan, organisasi politik, organisasi kemasyarakatan, dan perseorangan dalam pelaksanaan kehidupan bermasyarakat, berbangsa, dan bernegara.

Pengelolaan arsip yang baik dapat berpengaruh besar bagi kehidupan organisasi, mengingat jumlah arsip yang semakin banyak diciptakan dan diterima oleh instansi atau lembaga diperlukan pengelolaan arsip yang baik dan efisien. Penyimpanan arsipan tidak sekedar disimpan atau ditumpuk begitu saja tetapi perlu diatur dengan rapi dan ketika arsip dibutuhkan mudah ditemukan kembali. Dalam penyimpanan arsip di perlukan adanya sistem penyimpanan yang digunakan seperti sistem klonologis yaitu sistem berdasarkan waktu dokumen tersebut diterima atau dikirim, sistem abjad yaitu susunan menurut susunan abjad, sistem nomor yaitu penyimpanan berdasarkan kode nomor, sistem geografis yaitu berdasarkan pada nama temoat, sistem subjek yaitu berdasarkan kapada isi dokumen.

Dalam proses penyimpanan arsip yang baik dipengaruhi oleh peralatan dan perlengkapan yang digunakan untuk penyimpanan arsip. Peralatan tersebut digunakan agar membantu kegiatan kearsipan agar berjalan efektif dan efisien, seperti lemari penyimpanan arsip, map penyimpanan arsip dan sebagainya. Dalam pelaksanaan penyimpanan arsip setidak nya harus ditunjang oleh sumber daya manusia yang mampu mengoperasikan dan mengorganisasikan arsip secara baik dan benar agar arsip dapat tertata rapi sehingga arsip dapat mudah di temu kembali.

\section{B. METODE}

Metode penelitian yang digunakan dalam artikel ini adalah penelitian kualitatif deskriptif. Penelitian kualitatif merupakan 
Published by Program Studi Perpustakaan dan IImu Informasi FBS Universitas Negeri Padang, Indonesia

"salah satu prosedur penelitian yang menghasilkan data deskriptif berupa ucapan atau tulisan dan perilaku orang yang diamati" (Bogdan dan Taylor, 1992: 21-22).

Penelitian ini dipilih karena penulis hanya berupaya untuk menyajikan data secara sistematis, faktual, dan akurat mengenai faktafakta yang ada di lapangan. Penelitian ini dilakukan untuk menggali fakta mengenai pelaksanaan pengelolaan arsip Pada Dinas Pendidikan Sumatra Barat dengan menggunakan desain penelitian deskriptif dengan pendekatan kualitatif.

\section{HASIL DAN PEMBAHASAN}

Pelaksanaan penyimpanan arsip di Kasubag Kepegawaian ialah arsip-arsip yang yang diciptakan setiap harinya baik arsip masuk dan keluar yang sudah ditindak lanjuti atau di proses, disimpan di tempat penyimpanan yang sudah disediakan seperti map snelhecter, ordener, roll opack, filling cabinet dan lemari rak arsip yang disediakan di dalam ruangan Kasubag Kepegawaian.

1. Pengorganisasian Arsip
Di dalam pengorganisasian Arsip, yaitu siapa yang melakukan pengelolaan arsip dalam suatu organisasi. Agar ada kejelasan dalam hal pembagian tugas dan siapa yang menjadi tanggung jawabnya, menurut pengamatan penulis di Kasubag Kepegawain, pengelolaan arsip dengan cara desentralisasi yaitu Pengelolaan Arsip yang dilakukan pada setiap unit kerja dalam suatu organisasi atau setiap unit mengelola arsipnya masing- masing.

Dari hasil pengamatan penulis, yang bertugas dalam penyimpanan arsip yaitu pegawai yang tidak memiliki latar belakang pendidikan di bidang kearsipan. Selama ini arsip hanya dikelola oleh masing-masing pegawai yang bertanggung jawab atas masing-masing bidang kerja. Hal demikian dapat berpengaruh kepada efektivitas penyimpanan arsip.

Pengorganisasian yang dilakukan berdasarkan masingmasing tim bagian. Di ruangan kepegawaian ini terdiri atas 4 tim daerah bagian. Pertanggung jawaban arsip yang berada diruangan Kasubag 
Published by Program Studi Perpustakaan dan IImu Informasi FBS Universitas Negeri Padang, Indonesia

Kepegawaian diserahkan kepada masing-masing pegawai yang bertugas dalam mengelola dan menyimpan arsip tersebut berdasarkan tugas pokok yang telah di berikan. Dengan adanyan kejelasan siapa yang mengelola dan siapa yang bertanggung jawab, maka kegiatan pengelolaan arsip dapat dilakukan dengan baik. Sebaiknya penyimpanan arsip ditangani oleh arsiparis yang memahami arsip dengan baik.

2. Sistem Penyimpanan Arsip

Sistem penyimpanan adalah sistem yang dipergunakan untuk penyimpanan arsip agar pelaksanaan arsip dapat tertata agar mempermudah penemuan dokumen yang sudah diarsipkan jika sewaktuwaktu diperlukan.

Menurut Amsyah (1998:71) Sistem penyimpanan pada prinsipnya adalah menyimpan berdasarkan kata tangkap (caption) dari warkat yang disimpan baik berupa huruf maupun angka yang disusun menurut urutan tertentu. Pada dasarnya ada dua jenis urutan yaitu: (1) Urutan Abjad (Alphabetical Filing System), Urut abjad terdiri atas 3 sistem penyimpanan, yakni: a) Sistem Abjad, b) Sistem Geografis (Geographical Filing System), c) Sistem Subyek (Subject Filing System). (2) Urutan Angka (Numerical Filing System), yang terdiri atas: a) Sistem numeric (Numerical Filing System), b) Sistem Kronologis ( Chronological Filing System).

Menurut penulis dari hasil penelitian, Sistem yang di digunanakan dalam penyimpanan arsip di Kasubag Kepegawain secara umum yaitu sitem subjek, dimana penyimpanan berdasarkan isi dokumen yang dikumpul menjadi satu tempat seperti odner. Pada lemari arsip, odner di simpan berdasarkan geografis atau wilayah.

3. Perlengkapan dan Peralatan Penyimpanan

Dalam proses penyimpanan arsip yang baik di perlukan peralatan dan perlengkapan yang digunakan untuk penunjang dalam kemudahan penyimpanan arsip. Dewi (2011:156) menyatakan bahwa perlengkapan yang penting yang sangat diperlukan 
Published by Program Studi Perpustakaan dan IImu Informasi FBS Universitas Negeri Padang, Indonesia

untuk menyimpan arsip yaitu Lemari Arsip dan Tanda Sekat/Guide, dan Map/folder. Perlengkapan dan peralatan yang digunakan di Kasubag Kepegawaian yaitu:

a. Map Snelhecter, map yang terbuat dari bahan plastik dan didalamnya tersedia penjepit kertas, di Kasubag Kepegawaian map ini digunkan sebagai pelindungan dokumen agar dokumen tetap terjaga dengan baik, terkadang jika map besar odner terisi penuh, map snelhecter menjadi salah satu tempat untuk penyimpanan arsip.

b. Odner, odner adalah map besar dan tebal yang di dalamnya terdapat besi penjepit. Arsip yang akan disimpan di dalam ordner terlebih dahulu dilubangi dengan menggunakan perforator. Ordner terbuat dari karton yang sangat tebal sehingga cukup kuat jika diletakkan secara lateral pada lemari arsip atau rak arsip. Ordner dapat memuat kurang lebih 500 lembar arsip/surat.

c. Roll Opack, adalah lemari arsip dorong untuk menyimpan arsip dengan kapasitas besar, rool opack yang ada di ruangan Kasubag Kepegawain memiliki 4 bagian, setiap bagian lemari di beri label angka 1,2,3,4 yang menandai setiap bagian tim, maka dari itu pegawai akan menyimpan arsip sesuai dengan lemari yg telah di tentukan berdasarkan pembagian tim daerah. Lemari penyimpan lainnya yaitu filing cabinet, dan rak arsip.

d. Stapler, berfungsi untuk menyatukan satu dokumen dengan dokume lainnya dengan mudah.

e. Numerator, alat untuk membubuhkan nomor pada lembaran dokumen.

f. Perforator, merupakan alat untuk melubangi kertas, perforator yang digunakan di Kasubag Kepegawaian yaitu yang dua lubang sekaligus, yang selanjutnya akan ditempatkan pada odner, snelhecter dll.

g. Post-it, adalah selembar kertas kecil dengan potongan lem yang dapat direkatkan di sebagian punggungnya, post-it dibagian Kasubag Kepegawaian di gunakan sebagai penanda dokumen yang akan di tandatangani oleh atasan, sebagai penanda dokumen penting dan 
Published by Program Studi Perpustakaan dan IImu Informasi FBS Universitas Negeri Padang, Indonesia

sebagai pembatas dokumen atara satu dengan lainya.

4. Proses Penyimpanan

$$
\text { Dokumen-dokumen yang }
$$
akan di arsipkan yaitu dokumen yang sudah diolah, rekap dokumen sebelumnya, dokumen dari surat keluar, masuk dan dokumen yang diciptakan setiap harinya. Dokumen ini akan dikelompok kan berdasarkan isi dokumen semisalnya dokumen kenaikan gaji berkala dikumpulkan dengan sesamanya, dokumen SK dengan sesama dokumen SK, setelah itu dokumen yang sudah di kelompokan sesuai subjek akan di disusun berdasarkan tanggal, dimulai dari januari sampai desember. Dokumen yang sudah dikelompokan di beri lubang dengan menggunakan Perforator, setelah dilubangi dokumen di jepitkan di bagian dalam odner. Pada bagian punggung odner dibubuhi keterangan geografis, yaitu wilayah dokumen ini berasal, untuk mempermudah pencarian dokumen. Setelah itu odner akan disimpan dilemari arsip yaitu roll opack, odner akan disimpan sesuai bagian rak yang telah di bagi per wilayah/ per tim yang telah ditetapkan.

D. Simpulan

Arsip merupakan rekaman suatu kegiatan, yang sewaktu- waktu di perlukan sebagai sumber informasi, yang memiliki nilai guna di kemudian hari dan dapat dijadikan sebagai bukti untuk suatu tindakan dan keputusan. Arsip yang diperoleh bisa berbentuk naskah, dokumen, bisa berupa tulisan, gambar audio dan video.

Pengelolaan arsip yang di terapkan di Kasubag Kepegawain, dengan cara desentralisasi yaitu Pengelolaan Arsip yang dilakukan pada setiap unit kerja dalam suatu organisasi atau setiap unit mengelola arsipnya masing- masing. Sistem yang di digunanakan dalam penyimpanan arsip secara umum yaitu sitem subjek, dimana penyimpanan berdasarkan isi dokumen yang dikumpul menjadi satu tempat seperti odner. Pada lemari arsip, odner di simpan berdasarkan geografis atau wilayah. 
Published by Program Studi Perpustakaan dan IImu Informasi FBS Universitas Negeri Padang, Indonesia

Dalam proses penyimpanan arsip yang baik di perlukan peralatan dan perlengkapan yang digunakan untuk penunjang dalam kemudahan penyimpanan arsip seperti lemari arsip, odner, feeling cabinet, map, rak arsip, Roll Opack, Stapler, Numerator, Perforator, Post-it.

\section{E. Saran}

$$
\text { Adapun saran yang dapat }
$$

penulis berikan dalam pelaksanaa penyimpanan arsip yang perlu dipertimbangkan, sebagai berikut:

1. Alangkah baiknya seluruh pegawai diberi pelatihan dan pendidikan singkat tentang kearsipan.sehingga dapat melaksanakan pembenahan terhadap penyimpanan arsip agar dapat tercipta tatanan arsip yang efektif dan efisien.

2. Perlu adanya penambahan peralatan dan perlengkapan untuk pengelolaan arsip di ruang kepegawaian, peralatan dan perlengkapan yang cukup, menunjang terciptanya penyimpanan arsip yang baik.

3. Sebaiknya menggunakan sistem penyimpanan arsip yang seragam, agar pengelolaan penyimpanan arsip menjadi lebih mudah dilaksanakan dan dipahami oleh seluruh pegawai dan dapat lebih mudah dalam temu balik arsip.

\section{F. DAFTAR PUSTAKA}

Wirawanty, F. (2014). Tata Kelola Penyimpanan Arsip dalam Upaya Meningkatkan Efisiensi Penemuan Kembali Arsip di Kantor Perpustakaan Umum dan Arsip Kabupaten Pamekasan. Jurnal

Administrasi Perkantoran (JPAP), 2(2).

Susanti, E. S., \& Silvia, A. (2018). Analisis Efektivitas Dan
Efisiensi Penyimpanan Arsip.
Jurnal Ecogen, 15. Munawarah, S., \& Nelisa, M. (2012). Sistem Penyimpanan Arsip Dinamis di Pusat Arsip Balai Bahasa Padang. Ilmu Informasi Perpustakaan dan Kearsipan, 1(1), 234-241.

Fajri, H., \& Syahyuman. (n.d.). Sistem Pengelolaan Arsip Dinamis 


\section{Info Bibliotheca \\ Jurnal Perpustakaan dan IImu Informasi}

ISSN 2714-805X

Volume 1 Nomor 2, Juni 2020

Page : 82-89

Published by Program Studi Perpustakaan dan Ilmu Informasi FBS Universitas Negeri Padang, Indonesia

Aktif Di Kantor Perpustakaan, Arsip, Dan Dokumentasi Kabupaten Pesisir Selatan. Retrieved April 12, 2020, from Jurnal Ilmu Informasi Perpustakaan: ejournal.unp.ac.id/index.php/ iipk/article/view/1534/1335.

Winasari, K. 2017. Pelaksanaan Penyimpanan Arsip Oleh Pegawai Sub Bagian Umum Dan Kepegawaian Di Dinas Koperasi, Usaha Kecil Menengah Dan Perdagangan Kabupaten Ciamis. Dinamika: Jurnal ilmiah administrasi negara, 629-630.

Rusidi. (2014, April 25). Kewajiban Dan Tugas Lembaga Kearsipan Daerah Oleh: Rusidi. Retrieved Maret 12, 2020, from Dinas Perpustakaan dan Arsip Daerah Istimewa yogyakarta:

http://dpad.jogjaprov.go.id/a rticle/archive/vieww/kewaji ban-dan-tugas-lembaga- kearsipan-daerah-oleh-rusidi$\underline{648 .}$

Amsyah, Zulkifli. 1998. Manajemen Kearsipan. Jakarta: Gramedia Pustaka Utama.

Dewi, Irra Chrisyanti. 2011. Manajemen Kearsipan. Jakarta: Prestasi Pustaka Publisher.

Bogdan, Robert dan Steven Taylor. 1992. Pengantar Metode Kualitatif. Surabaya: Usaha Nasional.

Mulyadi. 2016. Pengelolaan Arsip Berbasis Otomasi. Jakarta: Rajawali Pers. 